\title{
MEDIA, STEREOTYPES AND MUSLIM REPRESENTATION: WORLD AFTER JYLLANDS-POSTEN MUHAMMAD CARTOONS CONTROVERSY
}

\author{
Rūta Sutkutè \\ Department of Public Communication \\ Vytautas Magnus University \\ 58 K. Donelaičio g., Kaunas, Lithuania, 44248 \\ Department of Communication \\ Kauno kolegija / University of Applied Sciences \\ 20 Pramones pr., Kaunas, Lithuania, 50468 \\ ruta.sutkute@stud.vdu.lt
}

\begin{abstract}
In the 21st century media has become the dominant source of knowledge of Islam and Muslims and selectively decides what the West should know about Islam and what should be hidden. However, the underlying assumption is that, the media as an institution forming stereotypes depends on the local socio-cultural context. The goal of this paper - to find out how media (as the mediator) forms values, world view of a society, creates stereotypes in different cultural environments through analysis of Muhammad cartoons. The objectives are: to define the concepts of Neo-Orientalism, Muslimophobia and Islamophobia; to find out the connection between media representations and negative images of Islam and Muslims in the society; to reveal the main stereotypes of Muslims and Islam in online media in 4 different countries by analysing the case of Muhammad cartoons.

The conducted qualitative and quantitative content analysis confirmed the hypothesis that in the specific cultures the same event is presented in different ways while forming value based orientation for a specific audience. Western media seeks to portray Muslims as terrorists / Islamists that are against West, their values and any possibility of integration in Western societies. Meanwhile, Lebanon and India (Kashmir) media does not portray orientalism and Islamophobic views, because audiences are dominated by Muslims. However there are noticeable manifestations of Occidentalism - resistance to the West and the Islamophobic portrayal of public in media. Moreover, information serves as a public mobilization function, so there are reasons to believe that violent protests in Kashmir and Lebanon could have been encouraged by the media.
\end{abstract}

Keywords: Orientalism, Islamophobia Jyllands-Posten Muhammad Cartoons, Media, Stereotypes, Muslim Representation, Stigmatization.

DOI: $10.21303 / 2504-5571.2019 .001054$

\section{Introduction}

In $21^{\text {st }}$ century, media became the main source of information. However [1], noticed the gap between the reality portrayed in media and the reality itself. The press emphasizes its mission to inform people by telling facts, presenting problems, giving different views, but the stories can be interpreted in subjective way and be given only to particular audience.

There is not enough attention drawn to manipulative (hidden) power that forms the social reality in political and other social sciences. The media points a particular problem, creates images of social figures, constantly presents objects and phenomenon how people should think [2]. However, there is not enough research done in order to claim these statements as facts. In $21^{\text {st }}$ century, media does not put enough attention to particular social groups' stigma - there is not much published research, related with marginalization of Muslims' societies.

It is thought, that media not only presents facts and truth the way they are, but is also a mediator, which helps to form a specific world view. Media portrays only the image of "the agreed reality" (as a stereotype), which can modify people's thinking, feelings, or behavior. The subjective information is incorporated to "common knowledge" or schemes that people have of specific groups [3]. Therefore this paper gives new insights of the media power, when forming specific orientation towards social exclusion of Muslims, loyalty, Islamophobia, identifying Muslims as “the other". Cartoons in Danish newspaper caused controversies, but the freedom of speech problem distracted attention from the core problem: racism, Islamophobia, xenophobia and Muslim's stigma in the press. 
The aim of this paper - to find out how media (as the mediator) forms values, world view of the society, creates stereotypes in different cultural environments through analysis of Muhammad cartoons. The goals of the study are: to define the concepts of Neo-Orientalism, Muslimophobia and Islamophobia; to find out the connection between media representations and negative images of Islam and Muslims in the society; to reveal the main stereotypes of Muslims and Islam in online media in 4 different countries by analyzing the case of Muhammad cartoons.

\section{Theoretical background}

The Media as an Institution that Forms Stereotypes and Values [4] claims, that "opinions are based on the premise that the media have significant effects" (p. 327). The media points the frame of references, used to interpret or discuss society events. According to [5], “They give a story a 'spin,' ... taking into account their organizational and modality constraints, professional judgments and certain judgments about the audience" (p. 120). [6] claims, that frames serve as "the bridge between ... larger social and cultural realms and everyday understanding of social interaction" (p. 13). While, [7] described these frames as "a central organizing idea or story line that provides meaning to an unfolding strip of events ... The frame suggests what the controversy is about, the essence of the issue" (p. 143).

Data and facts, presented in media, are selected from the large variety of information. Selectivity comes from the fact of attention and is encouraged by financial motives. The media itself decides which story should be shown, interpreted, and presented. This selectivity leads to the control of society beliefs and views $[8,9]$ claims, that from the moment, when people have limited possibilities to follow important events in the world, they are dependent on the press, which provides the right information. The main role of media is to provide facts from the outside world, but it shows a huge gap between what is given in the media and the reality. The reality is often hidden behind the media reality.

Stereotypes are described as "cognitive schemes, used by social activists in order to process information about others" [10]. They do not only reflect the beliefs about features of group members, but also give information about social roles. Stereotypes create expectations about other individuals "preliminary preparations to understand behavior and features, based on stereotypes" [11]. There is a stereotype that all members of group share "the same characteristics, views and living conditions" [12]. Stereotypes are described as simplified representation of social groups that rejects any variety (the difference) of same group members (ethnic minorities, women, etc.) [13].

The media presents stereotypes as "bias information, inevitably incorporated to common knowledge and to the schemes, which audience forms about stereotypical groups "[14]. Once these stereotypes are formed, they might be constant in the media. This can influence people's decisions and behavior towards particular social group. The process of association is defined as automatic "activation of associations in one's mind" [15]. This is the reason, why stereotypes are defined as the consequence of automatic associations about the group (minority) and its assigned trait, for example, the crime [16]. The West relates Islam with ethnic minority groups and immigration. One of the most discussed problems in public debates is the assimilation of Islam groups or limitation of Muslim minority rights [17].

In media discourse, [18] focuses on hidden power. It is the main component during analysis of media forming stereotypes and reality representation. There is a clear difference between the authors of articles and the audience. Even though the hidden power of media discourse depends on tendencies of news articles, it is named as manipulative power. It is because the production of media is deliberately manipulated by the ruling class in the society, so the language is one of the means to form reality. Media gives frames of the reality, which is not true [19, 20]. For example, racial stereotypes in the media are important, because they contribute to preserve racial myths while respectively giving associations between language and the context [21]. Language acts as a link to connect a specific label with the meaning or personal experience, that is a reason, why media is the element of socialization [22]. All above mentioned facts cannot exist separately, but they are related with specific assumptions. Therefore, the media acts as a link between social reality and the formation of specific social group stereotypes.

\section{(Neo)Orientalism and Means of Mass Communication}

There were a lot of changes since E. Said's book "Orientalism" [23] - the dependency between the West and Islam has completely changed. The Western dualism was changed due to glo- 
balization and evolution in presenting information, and that is why Orientalism turned to NeoOrientalism.

The important role of classical Orientalism depends on academic representations, however it has changed after the end of the Cold War. Now the main role of Orient belongs to media and the internet. In E. Said's book "Covering Islam" [24], the author critically analyses the Western press and the means, by which true Islam is hidden during 1980s. This book provided impartial and objective information, however the opportunity to give people the real truth was not used. In $21^{\text {st }}$ century, tendencies are the same as it was before the book; the media only selects the facts that the West should know about Islam. Islam is continued to be shown as outdated, despotic, retarded, hostile to Western Culture. The old stereotypes and values have not changed, however the author does not claim that research of social phenomenon can be fully objective. After all, scientists should admit and ask themselves, why and for what reason a number of research is being done, and in the Western countries, Islam is always closely related with dominance and conquest.

When the media mentions violence of Arabs or Muslims, [25] describes it as new tendency of Western media - the new barbarism. Violence is viewed as a main trait of a local culture, the most important trait of Muslims, despite the specific context. The author points out that the new barbarism is closely entangled with Neo-Orientalism, where cultural dualism between Islam and the West is emphasized. The two, mentioned above, are hegemonic strategies, when the creation of the enemy's image helps to legitimize economic and political projects of colonialism.

In $21^{\text {st }}$ century, Neo-Orientalism is directly related with revolution of mass communications and globalization. The hidden power of media discourse depends on the tendencies of news [26]. This notion brings the connection between Neo-Orientalism and Islamophobia, because the latter is related with means of mass communication. The pieces in media often encourage fear, hatred, hostility towards Islam. These result a negative face of Muslims and lead to Islamophobia [27].

The Comparison of Islamophobia and Muslimophobia

Anti-Muslimism provisions are deeply intertwined. The clash of the West and Islam is not a result of constant relation with other religions. This clash is highly likely to be influenced by nowadays problems but expressed through the same religion discourse. Problems, such as separation, segregation, violence, xenophobia, unsuccessful integration or discrimination, are related not only with religion [28], this is a clash of different lifestyles rather than the clash of civilizations [29].

British sociologist [30] describes Islamophobia as a process and Islamophobia as a result (the product). Discrimination (the result) that Muslims encounter may not be related with Islamophobia and in order to say otherwise, a proof of Islamophobic discourse is needed. Islamophobia is likely to be a mean that forms, sets and initiates prejudice, not a specific action. The lack of discrimination does not prove that this is not Islamophobia - the hostility towards Islam and Muslims can exist without discrimination. C. Allen points out 3 elements, which describe Islamophobia as a process: first, formation of stereotypes - the process which sums up the formation of images, setting the differences of Muslims and non-Muslims. Second, representation - the process of attitude and perception is formed through specific visual features, e.g. by matching hijab with fundamentalism. Third, semiotics - the mechanism, through which specific groups and perception of individuals become the norm, e. g. people who wear hijab are identified as the culprits of 9/11 terrorist attacks.

Islamophobia became one of the expressions of racism since it is based on hatred towards one group of people because of their religious beliefs, traditions, and ethnicity. The hatred towards Muslims and their discrimination is caused by negative stereotypes. In this case, racism is not only about the race, but also ethnicity, language, culture, religion. Islamophobia is not completely excluded from race, however, true racism is based on ethnicity, while in Islamophobia, words such as uncivilized, barbaric, violent, authoritarian are used to describe religious beliefs of Muslims and cultural practice. This idea slowly changes the concept of racial inferior, which becomes religious inferior. The change makes difficult to differentiate between Islamophobia and ethnic and racial hatred [31].

The expression of Islamophobia grows because of rapid changes, caused by globalization and the importance of media. Media not only reflects reality, but forms it, that is why media has be- 
come the main source of Islamophobia. For example, many scientists, intellectuals, politicians and public activists condemned 9/11 terrorist attack and encouraged to solve violent conflicts peacefully, however, they have failed to compete with the power of the media. Using events of 9/11, media proved their point to the West, showing the violent Muslims. They are presented as cruel, irrational, barbaric, and alien, while the West is viewed as modern, progressive, rational, civilized, humane and liberal - these traits give moral advantage in political, economic and social areas [32].

The main fear object of Muslimophobia is Muslims as citizens or residents of Europe, not Islam as religion. The fear in Europe rises because of Muslims; it is thought, that terrorist attacks of 9/11 might have influenced this fear. Muslimophobia is described as "new racism"; it is directed against culture or even the looks of Muslims. This notion covers reasons, why the media presents Muslims in the negative way, tries to find out, how much it depends on socioeconomic problems, power relations, political decisions, international conflicts, however Muslimophobia does not completely eliminate historical legacy. The composition of the notion has two dimensions - Muslims and phobia. The first is the main object, the second is phobia, which includes imaginary, non-historical, irrational fear towards Muslims.

\section{Materials and Methods}

\section{The Representation of Muslims in Online Media}

The time span of analysis of the media discourse: September $30^{\text {th }}, 2005$ and March $1^{\text {st }}, 2006$. On September $30^{\text {th }}, 2005$, twelve cartoons, depicting the prophet Muhammad, were printed for the first time in the conservative Danish newspaper "Jyllands-Posten". At the end of January cartoons were re-printed and it increased violent protests in more than 50 Muslim countries [33].

The representation of the holy prophet caused common dissatisfaction in the Muslim world, boycotts of Danish products, closure of embassies, violent demonstrations, suicide bombings. The cartoon crisis turned into political game where organizations and national states had to "choose sides". Islamic nations began to strictly and aggressively criticize "Jyllands-Posten". Many newspapers in Europe, the USA and Muslim world supported the right of "Jyllands-Posten" to publish cartoons. According to the survey of Danish journalism school (completed on $27^{\text {th }}$ February, 2007), all or some of "Jyllands-Posten" cartoons were printed out in 143 newspapers in 56 countries [34]. The majority supported the publication of cartoons with the argumentation of freedom of speech [35].

The sources for the research part are chosen according to:

1. The usage of the key word Muhammad cartoons;

2. The number of annual editions;

3. The availability of the article archive:

3. 1. The search system. The ability of internet websites to filter particular time interval or filter the newest and the most significant articles, as well as by key words.

3. 2. Financial aspects. Some articles are not for free. However, the quality of the article does not depend on price, so all paid internet websites are not included.

4. Statistical data. The amount of Muslims, living in certain country, their status, relations with the rest of the society.

These internet websites are chosen according to all above mentioned criteria:

1) greaterkashmir.com - "Greater Kashmir" (India).

Muslims are a minority in India, Islam is the second religion $-13 \%$ of people are Muslims. However, conflicts between Muslims and Hindus are unavoidable from 1947 [36]. Kashmir is the Muslim region, where the largest protests appeared. Indian Muslims are often called as a conflict minority and they hardly find balance in India, because they tend to keep their religious and cultural heritage, which might cause a threat to the Hindus. There is a high probability that Hindus would lose the majority status in Kashmir [37].

2) nytimes.com - "The New York Times" (The United States).

There are less than $1 \%$ of Muslims in the US [38], on the other hand the media constantly presents Muslims and Islam in the negative way. A survey revealed that almost half of American people ( $46 \%$ ) have a negative opinion towards Islam; (this number rose immediately by $7 \%$ after 9/11 terrorist attacks). Also, Americans believe that all Muslims are in favor of violence [39]. When 
Muhammad cartoons were published, the US public diplomacy was emphasizing the support to Islam because of wars in Iraq and Afghanistan, so the most of the US newspapers (including "The New York Times") refused to publish these cartoons [40].

3) independent.co.uk - "The Independent" (The UK).

Islam is the second religion in the UK, almost $4.8 \%$ of people are Muslims [41]. $81 \%$ of Islam followers identify themselves as Muslims, $86.4 \%$ of them think that their identity is related with the UK [42]. However, mass media still presents Muslims and Islam in negative way, especially after 9/11 terrorist attacks [43].

4) dailystar.com.lb - "Daily Star" (Lebanon).

Islam is the dominant religion in Lebanon - $54 \%$ people are Muslims [44]. Because of this reason, Lebanon is thought to fit for this comparative analysis. It can be noted, that presentation of news in the West and in Arab counties is different because of context [45]. The tendency of Lebanon media is to present the opinions and views rather than news and facts themselves and this allowed to form the public's opinion. There is a lot of skepticism towards the objective information, because each type of media supports and represents a particular religious group.

\section{Research Results}

\section{Results of Quantitative Content Analysis in Muhammad cartoon Crisis Discourse}

1062 publications were found in websites by searching key words "Muhammad cartoons". 120 publications were analyzed with qualitative content analysis; 30 publications from 4 different countries (key words Muhammad cartoons were related with the main topic). The analysis of internet publications was carried out, collaborating quantitative and qualitative research methods. However, the primal analysis proved that qualitative content analysis is more suitable to get the most accurate data of the press as a mediator. Quantitative research was used as an additional method to check the tendencies of main key words.

The quantitative analysis showed the frequency of 4 concepts/word combinations: Islamism/ terrorism; anger/violence; different values; freedom of speech (Fig. 1). The results showed that concepts Islamism/terrorism (in 115 articles) and anger/violence (in 121 articles) were the most frequently used. The word combination different values was not often used in articles, on the other hand, it fits the topic of the most articles. In media, stereotypes are usually created by using specific language, so it is thought, that this usage might artificially create the hostility among all groups in the society. Also, these concepts were found in the headlines of articles, when presenting events, related with Muhammad cartoons. Assuming the fact above, the headlines indirectly create stereotypes while using specific negative concepts or word combinations, especially in Western media.

To sum up, the data, gathered in the quantitative analysis was used in the qualitative content analysis. This data was useful to predict some tendencies of the media as a mediator to not only present objective information but also to form an orientation of the audience.

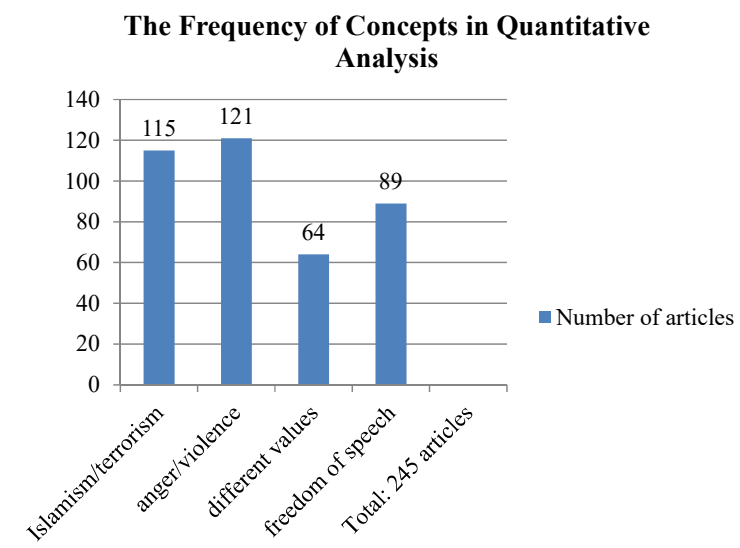

Fig. 1. The Frequency of Concepts in Quantitative Analysis. Source: made by the author according to the data, gathered during the quantitative research 


\section{Results of Qualitative Content Analysis in Muhammad cartoon Crisis Discourse}

Further on this paper, the results of the qualitative content analysis are presented. The information, provided in the US, the UK, Lebanon and Indian media, is compared and analyzed. Also, media is analyzed as a mediator, which forms values and/or stereotypes towards Islam and Muslims. The results are introduced according to 2 dominant presentations of Muslims: Islam tendency towards violence and the threat to Western values because of freedom of speech in the context of Muhammad cartoons.

The Threat of Islamism and Islam Tendency Towards Violence

Islamism can be considered as one key word, when analyzing the role of the media, forming certain values in the case of Muhammad cartoons. Qualitative content analysis includes concepts Islamism/terrorism in order to see the main tendencies in articles, even though concepts are not directed to Islamism (as a movement with the goal to separate Western culture from Islam culture). According to the analyzed articles, Islam has a tendency towards violence or an ambiguous connection with violence (as a main feature of the culture), so this can create a cognitive model, where fear and misunderstanding are main components. It is noted, that most articles raise the question, if Islam and Western society match together. "The New York Times" claims "Islam is the Europe's fastest growing religion and is now the second largest religion in most European countries. Racial and religious discrimination against Muslims in Europe's weakest economies adds to the strains" [46].

"The New York Times" and "The independent" newspapers are quoting the representatives of Catholic Church, where they express deep concerns about the connection between Islam and violence. Based on this claim, Muslims are classified as enemies of the Western society. Soren Krarup, a retired priest, said "The Muslim response to the cartoons showed that Islam was not compatible with Danish customs. He said, Jesus had been satirized in Danish literature and popular culture for centuries - including a recent much-publicized Danish painting of Jesus with an erection - so why not Muhammad?" [47]. Priest also adds that Muslims must integrate to the society "Muslims, who come here, reject our culture. Muslim immigration is a way for Muslims to conquer us, just as they have done for the past 1,400 years" [48]. Western media purposely creates the negative image of Muslims by presenting violence as a main feature of Islamic culture. Journalists as creators of articles select what is suitable for the audience, in accordance with the interest of the audience and relevance of an article. The quote, given above, shows the clear indication to Orientalism - the repetition of history. Islam and Muslims are viewed as a threat, because they keep trying to conquer the West the same way they were doing "1400 years ago". For this reason, Europe constantly feared barbarian and uncivilized Orient.

Considering this statement and other mentioned facts about Islam, the author of the article indirectly causes concern by forming a specific frame of Orient. It is a strategy, where the author claims that Christianity and Christians are peaceful and liberal, while Islam and Muslims are defined as violent and tyrant people, who do not care about main democratic values. These facts support public concern about violence of Muslim and can encourage hostility to Muslims. This presents one feature of Orientalism - dualism, which creates dichotomy between we and they. It stays within an article and keeps forming the negative opinion towards Muslims and Islam. However, the main instrument of creating the negative opinion about Muslims is mass media. Creation of identity always involves creating the other object (high likely with negative hostile characteristics). That other identity is considered inferior and flawed as in this case the Muslim identity. All above mentioned facts can influence discrimination of Muslims in the society.

According to the already listed facts, Muslims are given two possibilities: either unconditionally follow their lifestyle, which is closely related with their religion or adapt to the Western lifestyle and values. Concern is created by presenting Muslims to the audience as the ones, who will Islamize the society. When concepts of fundamentalism and Islamism are given together, they indicate violence and this is how Muslims are presented: fundamentalists, radicals, terrorists, threat to Western society and culture "In Pakistan, blasphemy laws have been used by fundamentalists to attack Christians and Hindus" [49]. The article creates pictures of Islam as violent (as a main feature), because the publication uses statements that connect Muslims and Islamism. 
The aspect of Orientalism is important in the Western mass media ("The New York Times" and "The Independent"). Here, Islam is viewed as a dangerous object because of history clashes with Christianity or Hinduism: Islam civilization will fight against the Western Christianity and will be expansionary. Because of these presentations, Europeans always viewed Islam as barbaric and uncivilized. However, these stereotypes remain, just the understanding of the other in $21^{\text {st }}$ century is related with the new concept of Islamophobia and identification of Muslims after 9/11 terrorist attack.

Author's articles constantly emphasize that the ones, who are protesting against insults to Islam, are portrayed as fanatics, related with terrorism and Islamism. One of articles in "The Independent" newspaper has screaming posters, such as "Bombard the West", "Cut their heads off", "We must kill those that insult prophet Muhammad" [50]. What is more, Australian journalist writes:

"When Muslim extremists got to hear of the not very funny and not at all biting cartoons that appeared at the end of September in the Danish newspaper Jyllands-Posten, illustrating an article on the difficulty of finding an artist to draw Mohamed's face for a children's book about Islam, they rubbed their hands. Here was a great opportunity for their favorite game, pandemonium. A few dozen men, calling themselves the Islamic Defender's Front, in dazzling white and Muslim green, came in a body, howling like a lunatics to "attack" the Danish embassy with rotten eggs" [51].

This depiction is closely related with Islamophobia, however after hearing the term Islamophobia, the first association - Muslim communities in the West. Fear, hatred, hostility to Islam and Muslims are created by the narrow view and lack of awareness, which can cause negative stereotypes and beliefs about Muslims. After the discourse analysis, it can be noted that the Western media forms negative stereotypes towards Muslims because both internet newspapers present Islam as a violent religion and Muslims are Islamists. These descriptions only encourage the stereotypical belief that Muslims are terrorists from the beginning. When the religious group is presented with violent characteristics, the audience will assign this trait to all Muslims and it is the reason, why all Muslims will be greeted with prejudice and discrimination [52].

[53] named the new tendency of the West as new barbarism, because violence is shown as a main characteristic of Muslims and the most important trait. 15 headlines of articles in "The New York Times" and "The independent" put the emphasis on deaths in countries, such as Pakistan, Lebanon, Indonesia, Malaysia, where the biggest protests occurred. "Two Killed in Violent Protests in Two Pakistani Cities" [54]; "3 More Die in Pakistan Cartoon Protests" [55]; "2 Die as Pakistan Cartoon Rage Turns Violent” [56]; "Ten killed as cartoon protests spread to Libya” [57]. In order to form negative values, where Islam is solely associated with violence, the emphasis is not only put to the behavior of protesters, but also to the posters that serve as links or allusions to negative traits of Muslims and Islam: "During the spontaneous February 3 march from the Central London Mosque to the Danish Embassy protesters praised the "magnificent" 9/11 hijackers and waved placards with messages, such as "Massacre those, who insult Islam", "Europe you will pay" and "Europe you'll come crawling when Mujahideen come roaring" [58]. The article includes details of 9/11 terrorist attacks, so it can be claimed, that information is limited by the social context. 9/11 terrorist attacks have strongly influenced the negative identification of Muslims and caused Islamophobia in the Western society.

What is more, the most authors of articles in "The New York Times" and "The Independent" are not representing Muslims, so this may be the reason, why Muslims are presented in the negative way in both the UK and the US media. The West is the audience of an article. As the result, here the West encounters with Muslim integration problems, different values, or clash of civilizations.

The qualitative content analysis showed a few alternatives: in one of the analyzed articles the author Yasmin Alibhai-Brown states that the problem of negative Western prejudice towards Muslims and Islam is the result of failed integration. The West is intentionally keeping Muslims in the shadow and trying to apply double standards:

"What they have done, in fact, is belittle freedom of expression. They have taken something precious and turned it into a license for the intelligentsia to behave like yobs.". $<\ldots>$ These liberal warriors, high on conceit, want to demonstrate that Muslims can never be a part of Europe, because, well, they are too backward to hoot aloud when their revered prophet is shown with a bomb for a turban. I am not amused either, so should I pack the bags? Many of these countries were infamous for their state terrorism against Jews. Since then they have systematically mistreated generations 
of Muslims. Right on cue, out came the dishcloths, Bin Laden surrogates with murderous banners and belligerence" [59].

This is one of a few examples, which provide information about social reality in the Occident, where Muslims are stigmatized and marginalized with negative stereotypes. The negative opinion about Muslims is formed by only one-sided Western authors' view which is favorable to the dominant view of the audience.

According to the discourse analysis, the majority of publications in Indian (Kashmir) media are author's articles. Their surnames, positions and home countries revealed that they are representatives of the Islamic world. The media is restrained by the local sociocultural context so the expression of Orientalism is limited. The biggest problem for the East is the West that believes its universal culture and irreplaceable hegemony in the world [60]. Both India (Kashmir) and Lebanon media have notions of Occidentalism that is complete opposite to Orientalism. Occidentalism presents the West without values, full of imperialism incentives, constant organization of attacks, which main goal is to assimilate or destroy other cultures. Occidentalism / Occident - a belief that Western lifestyle is evil by nature and everyone, who lives by Western lifestyle, is inhumane [61].

The prominence is present in newspapers "Daily Star" (Lebanon) and "Greater Kashmir" (India). Islamism, terrorism and other expressions of violence are presented from different aspects. Here, Islamophobia is used to characterize social reality in Western liberal democracies. Islamophobia is a tool that constructs the view of Muslims and Islam as the other completely opposite, hostile and violent object. One of the main authors of Indian newspaper Hassan Zainagairee notes "The history is repeating itself. It is a standard to demonize Muslims and Islam in the West" [62]. The effort of the West to insult the prophet of Islam drew worldwide attention, because "Danish cartoons showed our beloved prophet as a terrorist" [63]. Historically, there is no difference if Muslims are keeping their power or are dealing with repression - in either way they are the object of mockery. When colonialism increased in $19^{\text {th }}$ century, Muslims encountered with cruel and humiliating actions of Occident and from that time people still see Muslims with the same orientalist image [64].

[65] points out that there is a tendency in the West and India to demonize Muslims and Islam. This is an obvious effort to insult and belittle the prophet of Islam by using his negative and violent characteristics. The analysis of these cartoons confirms that Islam and Muslims here are presented in a different way. Indian and Lebanon media do not present Islam as violent. They claim that violent protests restrict enlightenment of Islam. The details of Orientalism in the media are limited by the sociocultural context of Kashmir and Lebanon, because the audience consists of Orient representatives.

The mass media socializes, informs, mobilizes and forms the opinion of the audience. Kashmir (India) and Lebanon media not only constructs the images, where the emphasis is on Western Islamophobia, but also the media mobilizes the society. Texts are written in the way that the audience will have their own opinion and it gives more freedom, which articles to print and which to exclude. This influences mobilization, because the opinion from the media can support particular idea or action. After the discourse analysis, it can be confirmed, that statements of religious activists and Muslim's publications might have influenced violent protests (statistics show that at least two protesters died in Lebanon) [66].

The media mobilizes the audience in the chosen countries (India (Kashmir) and Lebanon), where majority of people are Muslims. The media gathers the audience from both countries, while pointing out the illegal actions of the West. As an example, the leader of "Hurriyat conference" [67], Mirwaiz Muhammad Umar Farooq is quoted "natural reaction to blasphemous acts and Muslims think that they are right and have a full right to act with violence. According to the complexity of this violation, no other measures can be applied" [68]. This quote proves that protests and violence are an appropriate reaction to the behavior of the West. Parties of Hurriyat Conference are a political unit, formed with 26 political, religious and social institutions in Kashmir - this is the reason, why this unit is an essential authority [69]. These quotes of politicians not only form a specific orientation towards the West but also bring the society together. "Daily Star" (Lebanon) claims that protests express the legitimate anger [70]. Concepts such as obvious reaction, proven reason, legitimate anger allow violent protests against Muhammad cartoons. 
One of articles "Indian Muslims urge the government to end silence on blasphemy" quotes the Indian imam Maulana Syed Ahmed Bukhari "Government, like the ruling party in Congress must condemn this cruel act and pass the pain of Indian Muslims to Danish government and other counties that printed these cartoons" [71]. Also, the article criticizes the Prime minister Manmohan Singh, who was silent about cartoons. The statement of the imam as well as one of the leader of "Hurriyat conference" should be considered as acceptable and not questioned, because they are an authority and their opinion is crucial in the religious society.

Indian (Kashmir) and Lebanon media successfully provides information while selecting statements of public figures, which will be acceptable and understandable for the audience.

To sum up the conclusions, which are related with Islam as stereotype of violence, it can be said, that Western media tends to keep this stereotype (Muslims as terrorists or Islamists), while putting the emphasis on their violent actions. There is no Orientalism and Islamophobia hints in Lebanon and India (Kashmir), because the majority of the audience is Muslims. However, this causes Occidentalism - the resistance to the West and the portrayal of the Islamophobic society in the media. But the newspapers "Greater Kashmir" and "Daily star" puts the Muslim society together and encourages protests as an obvious reaction to the controversy of Muhammad cartoons.

The Threat of Muslim and Islam to Western Values in the Context of Freedom of Speech

Before analyzing the media of 4 different countries, it is important to note that there is a problem of the freedom of speech and religious tolerance in the Muhammad cartoon crisis. Western countries, especially the UK, stress the freedom of speech, while showing Muslims as representatives of hostile values.

The discourse analysis confirmed that Islam is considered as a source of nuclear weapons, terrorism, unwanted emigrants in the West. What is more, it is confirmed, that ideas, such as individualism, liberalism, constitutionalism, human rights, democracy, free market, secularism do not meet up with Islamic values. The effort of the West to spread these ideas encouraged reaction against Western universalism - when all above mentioned principles became a new tool of colonization, where the media has the ability to affect values of the society. The ones, who own the media, are powerful figures, because they can control the construction of representation and according to social constructivism, it is controlled what is real. The media can turn a society to the passive news receiver, not the investigator, who searches for hidden meanings. The Western media was trying to enforce hostility towards the Muslim society and it was called the clash of values - freedom of religion and freedom of speech and clash of civilizations between secular Western democracies and Islamic societies [72].

"The New York Times" and "The Independent" quote Danish politicians and society figures. Kurt Westergaard (the author of one of cartoons), Danish cartoonist: "No regrets. Kurt Westergaard risked more fury by saying that his inspiration for the pictures was "terrorism", which he said received "spiritual ammunition" from Islam. He spoke out as a Pakistani cleric yesterday put a $\$ 1 \mathrm{~m}$ bounty on his head. He is in hiding and hinted to The Herald that the Danish secret service, PET, was guarding him" [73]. The focus of the article is on the freedom of speech and on the imam of Pakistan, who offered bounty to kill the cartoonist, so here is an antithesis to freedom of speech - the imam's approval for violence. Also, here is visible bound between good and bad, the contrast emphasizes the opposition between Islam and Western culture.

The UK newspaper states that the Danish newspaper "Jyllands-Posten" contributed to "Worldwide debate on how to balance democracy and freedom of expression with respect for religious belief" [74]. However, the Danish cartoons only encouraged mass violent protests and Muslim's dissatisfaction in the world. The worldwide discussion turned into violent worldwide protests, where couple dozens of participants were killed. This proved the main function of media - to provide particular references, how the Western society should evaluate the reaction of Muslims to cartoons, which only defended one of the main democratic values - freedom of speech and press. It is clear, that media is a mediator only in the specific cultural environment, which is a decisive fact for given news. Muslim has a minority in the UK society this is why possibilities of Muslims in forming public opinion are limited. The media represents interests of the society majority, forming and supporting the universally accepted provisions. One of them is the opposite of Muslims and Islam towards values of the 
secular society: stable and exceptional role of religion in the Muslims' society strengthens the opinion of the West that Islam and democracy are absolutely incompatible [75].

Contrary to the UK, Denmark and other European countries, the main objective of US public diplomacy is to emphasize the support to Islam because of wars in Iraq and Afghanistan. Many newspapers of the US, including "The New York Times", did not publish cartoons with the argument that history can be told without insulting pictures. In addition to this, the administration of G. W. Bush offered the support for protesters, commenting on the cartoons "We find them offensive, and we certainly understand, why Muslims would find these images offensive" [76]. The US was trying to gain its reputation back in the Arabic world after the war in Iraq with the constant support for Israel. As well as most politicians, the press representative Sean McCormack said: "Anti-Muslim images are as unacceptable as anti-Semitic images," which are routinely published in the Arab press, "as anti-Christian images, or any other religious belief" [77].

The opinions of the UK and the US are regarding freedom of speech clashed, so the presentation of the problem of Muhammad cartoons is different in the media. The US supported freedom of speech as well as religious tolerance and Muslims' minorities. One article gives the opinion of American Muslims, where Muslims appreciate the freedom of speech, but governments in the US should condemn all cartoons, which are full of hatred. Also they encouraged to give more effort, integrating Muslim minorities: "The reason that Muslims in America have not responded the way they have in Europe is that we have come to know that so many people here speak out against such bigotries, and so many newspapers have not published the cartoons" [78]. The leaders of American Muslims claimed to Danish ambassadors that they lived in America longer than many other Muslims lived in Europe and despite all obstacles, Muslims managed to create effective organizations, to reach larger integration and economic success than their brothers in Europe. However, Muslims in the US are also fighting against Islamophobia and discrimination, but they created strategies how to solve these issues, so Danish Muslims should learn from US Muslims and become more united [79].

It is assumed, that hostile prejudice towards Muslims and Islam influences the radicalization of the Muslim minority and clash of cultures, written by Samuel P. Huntington. This prejudice tries to separate the US, where problems like these are minimum, and Europe, where Muslims fail to integrate. What is more, contrary to the US media, the emphasis in European media is on xenophobia, discrimination, racism, conditions, not suitable for immigration, unsuccessful integration. This is the reason, why Muslims are not perceived as a threat to US and its society. Though the provisions of the society and politicians of US and Europe are against immigration, the US media shows that the situation in the US is opposite because of successful multicultural implementation of politics.

Nevertheless, only one article in newspaper "The New York Times" tried to defend the interests of the Muslim minority [80]. It is important to note, that formation of the particular world view depends on the quotes of political figures. This article presents the opinions of Muslim representatives in the West that is why the attitude is positive towards the Muslim minority. It is claimed, that there is a necessity to integrate Muslims, minimize the exclusion in the society, change the attitude and stereotypes.

On the other hand, Indian (Kashmir) media identifies freedom of speech as the right of the West to insult Muslims and Islam. This is mentioned in article "The row over the Danish cartoons". It states that hypocrisy is still present in the Arab world, because Jews have a right to protest against their stereotypes while Arabs cannot. The article notes that the insult of Muslims is considered as freedom of speech, while the creation of Arab terrorist in the Danish cartoon is not just freedom of speech, but it an insult for all Arabs and Muslims' dignity [81]: "Though the West claims to be enlightened, civilized and to respect the religious beliefs of other, however nourishing Western values they put masks of hypocrisy" [82]. In this cultural environment, the understanding of freedom of speech is different from the Western world, because it is considered as Western dominance and a tool of racism, since in history, Europe always was on the top of power and had dominance over Orient.

The topic of antisemitism is present in articles, regarding freedom of press, freedom of speech and religious tolerance. There is a constant search of examples, which proves negative prejudice of the West towards Muslims and Islam. In other words, antisemitism (the hostility and prejudice towards Jews) is used as an analogy in order to show an unreasonable hostile approach to Muslims. Islam became 
the most quickly spread religion in $21^{\text {st }}$ century in the West. [83] notes that terrorism can be related with the old stereotype, which is still present in people's heads, so racism, directed to Muslims in Western Europe, is similar to anti-Semitism, because both concepts express discrimination to the particular group of people. Muslims are viewed as an imaginary society [84], which has common values and behavior standards. For this reason, the public discourse constantly emphasizes the differences between locals and Muslims and this only deepens hostility, which can lead to racism and discrimination.

3 articles in the newspaper "Greater Kashmir" mention Zionism. The leader of "Hurriyat" conference Mirwaiz Muhammad Umar Farooq states that Danish cartoons are conspiracy of Zionism: "The forces of zionism created those basphemous acts towards Prophet Muhammad. They stood behind freedom of speech and freedom of press" [85]. Other article also agrees that cartoons are part of conspiracy which was created by colonists and forces of Zionism against Muslims and Islam [86]. Antisemitism is also present in Lebanon newspaper articles, but it is interchanged to hostility towards Muslims, emphasizing the social dimension. For example, Arab League Secretary General Amr Moussa decried the double standards in the European media "Muslim anger boils over Danish cartoons. We see double standards in the European media, which is fearful of being accused of anti-Semitism, but which invokes freedom of expression for a caricature on Islam" [87]. These acts of the West are named as cultural terrorism not as self-expression, freedom of press and freedom of speech, as it is common in Western media [88].

What is more, Lebanon and Indian (Kashmir) media connects Islam to Judaism. H. Zainagiree points out: "The hostility of antisemitism is transferred to Arabs, because Arabs and Jews are semits of Orient" [89]. It can be assumed, that the media remembers the history of Semitism to bring the image of the Holocaust. This creates the particular view of the audience towards the West, like in all times of history, forging the hatred to religious groups. This is the main reason why there is an indirect requirement to fight back this dominance, because $19^{\text {th }}$ century has already ended. This statement proves the one of the main arguments of the analysis: the media enlightens the society not only with relevant information but also with specific values, in this case - the negative Western opinion and its politics towards Muslim minorities in the Western societies. However, in $21^{\text {st }}$ century, the media sets clear boundaries for the audience which should be used to understand and interpret specific society actions and phenomenon.

To sum up the third stereotype (hostility of Muslims and threat to the Western values), it can be noted, that Western articles focus on freedom of press and freedom of speech not taking into account the blasphemy. However, the representatives of the US Muslims portray social reality as not forming values towards Muslims or mobilizing representatives of the Muslim minority to fight against Occident. This proves the point that the content of an article depends on author, quoted people and audience of an article. On the other hand, the newspapers of Lebanon and India (Kashmir) associates freedom of speech with the Western right to insult Muslims and Islam. What is more, if the article states details about freedom of press and religious tolerance, the topic of antisemitism appears, (except the US and the UK newspapers). In other words, the article tries to present some historical evidence that could justify the Western prejudice against Muslims. However, in $21^{\text {st }}$ century, previous hostility and unreasonable fear for Judaism is transferred to Muslims and Islam.

\section{Conclusion}

After the analysis of connections between Orientalism and Islamophobia and negative stereotypes in the media, it is set, that dualistic Orient and Occident separation is one of the most important factors, when presenting Orient, its culture and religion. Western media selects only facts that the West should know about Islam, because Islam is kept being view as outdated static, irrational and the repetitive phrases, such as Islamism, terrorism, violence only encourages hostility towards Muslims and Islam. In the environment, where the majority of the audience thinks about Muslims as terrorists and fear them, the authors of articles try to show fear in headlines and present events by using specific terms.

According to the discourse analysis in the context of Muhammad cartoon crisis in 4 different countries media, the presentation of Muslim and Islam in the media depends on local socio-cultural context. Articles in the media are created in the way, so the audience will take certain measures 
and form provisions in favor of the majority of the society. The results of the analysis show that in the Western media "The New York Times" and "The Independent" Muslims are portrayed as the homogenous society, whose members are in favor of violence, hostility, fanaticism and rejection of every opportunity in Western societies. The most common stereotypes in articles are MuslimsIslamists / terrorists; Muslims - against freedom of press and freedom of speech. Indian (Kashmir) and Lebanon media forms opposite values and information in newspapers mobilizes the society, so there is a basis to think that violent protests are caused by the media.

After the comparison of how different representative groups are participating in the construction of Muslim and Islam stereotypes, it is revealed, that the content of an article depends on author. Western media quotes many politicians, writers and journalists, who encourage the marginalization and stigmatization of Muslims and reproduction of Islamophobia. The language, used in articles, creates dichotomy between $u s$ and they, which add to the negative society opinion about Muslims, because the alleged threat to the western security and values are related with the image of extremist, radical, terrorist, Muslims. On the other hand, Lebanon and Indian (Kashmir) media quotes religious leaders, imams. Their quotes are with the details of Occidentalism - the resistance to the West and are portrayal as the Islamophobic society, including antisemitism.

\section{References}

[1] Lippmann, W. (1922). Public Opinion. Oxford: Harcourt, Brace, 427.

[2] Fairclough, N. (1989). Language and Power. London: Longman, 248.

[3] Lowery, S. A., De Fleur, M. L. (1988). Milestones in Mass Communication Research. New York: Longmanm, 488.

[4] McQuail, D. (1994). Mass Communication Theory: An introduction. Thousand Oaks: Sage.

[5] Neuman, R. W., Just, M. R., Crigler, A. N. (1992). Common Knowledge. News and the Construction of Political Meaning. Chicago: University of Chicago Press, 190.

[6] Friedland, L. A., Zhong, M. (1996). International Television Coverage of Beijing Spring 1989: A Comparative Approach. Journalism \& Mass Communication Monographs, 156, 1-60.

[7] Gamson, W. A., Modigliani, A., Braungart, R. G., Braungart, M. M. (1987). The Changing Culture of Affirmative Action. Research in Political Sociology. Greenwich: JAI Press, 3, 137-177.

[8] Hilton, J. L., von Hippel, W. (1996). STEREOTYPES. Annual Review of Psychology, 47 (1), 237-271. doi: http://doi.org/10.1146/ annurev.psych.47.1.237

[9] Dovidio, J. F., Hewstone, M., Glick, P., Esses, V. (2010). Prejudice, Stereotyping and Discrimination. London: SAGE Publications, 3-28. doi: http://doi.org/10.4135/9781446200919.n1

[10] Liebert, R. M., Sprafkin, J. (1988). The Early Window: Effects of Television on Children and Youth. Boston: Allyn \& Bacon.

[11] Perse, E. M. (2008). Media Effects and Society. New York: Routledge.

[12] Ramasubramanian, S. (2007). Media-based Strategies to Reduce Racial Stereotypes Activated by News Stories. Journalism \& Mass Communication Quarterly, 84 (2), 249-264. doi: http://doi.org/10.1177/107769900708400204

[13] Strack, F., Deutsch, R. (2004). Reflective and Impulsive Determinants of Social Behavior. Personality and Social Psychology Review, 8 (3), 220-247. doi: http://doi.org/10.1207/s15327957pspr0803_1

[14] Arendt, F. (2013). Dose-Dependent Media Priming Effects of Stereotypic Newspaper Articles on Implicit and Explicit Stereotypes. Journal of Communication, 63 (5), 830-851. doi: http://doi.org/10.1111/jcom.12056

[15] Verkuyten, M., Slooter, L. (2008). Muslim and Non-Muslim Adolescents' Reasoning About Freedom of Speech and Minority Rights. Child Development, 79 (3), 514-528. doi: http://doi.org/10.1111/j.1467-8624.2008.01140.x

[16] Bell, A., Garrett, P. (1998). Approaches to Media Discourse. Oxford: Blackwell, 470.

[17] Davis, D. K., Wilson, J., Harris, S. J. (1988). Language, media, and communication: Part I. Critical Studies in Mass Communication, 5 (1), 71-82. doi: http://doi.org/10.1080/15295038809366686

[18] Popp, R. K. (2006). Mass Media and the Linguistic Marketplace: Media, Language, and Distinction. Journal of Communication Inquiry, 30 (1), 5-20.

[19] Gorham, B. W. (1999). Stereotypes in the Media: So What? Howard Journal of Communications, 10 (4), 229-247. doi: http:// doi.org/10.1080/106461799246735

[20] Said, E. W. (1978). Orientalism. New York: Pantheon, 368.

[21] Said, E. W. (1981). Covering Islam. London: Routledge and Kegan Paul.

[22] Tuastad, D. (2003). Neo-Orientalism and the new barbarism thesis: Aspects of symbolic violence in the Middle East conflict(s). Third World Quarterly, 24 (4), 591-599. doi: http://doi.org/10.1080/0143659032000105768 
[23] Samiei, M. (2010). Neo-Orientalism? The relationship between the West and Islam in our globalised world. Third World Quarterly, 31 (7), 1145-1160. doi: http://doi.org/10.1080/01436597.2010.518749

[24] Kayaoğlu, T. (2012). Three takes on Islamophobia. International Sociology, 27 (5), 609-615. doi: http://doi.org/10.1177/ 0268580912452360

[25] Triandafyllidou, A. (2010). Muslims in 21st Century Europe: Structural and Cultural Perspectives. New York: Routledge.

[26] Huntington, S. P. (1996). The Clash of Civilizations and the Remaking of World Order. New York: Simon and Schuster.

[27] Allen, C. (2010). Islamophobia. London: Ashgate.

[28] Esposito, J. L., Kalin, I. (2011). Islamophobia and the Challenges of Pluralism in the 21st Century. New York: Oxford University Press.

[29] Weaver, S. (2010). Liquid Racism and the Danish Prophet Muhammad Cartoons. Current Sociology, 58 (5), $675-692$. doi: http://doi.org/10.1177/0011392110372728

[30] Kruse, H. N. (2006). 143 aviser viser tegningerne. Danmarks Medie- og Journalisthøjskole. Available at: http://www.djh.dk/ ejour/52/52Tegninger1.html

[31] Olesen, T. (2009). The Muhammad cartoons conflict and transnational activism. Ethnicities, 9 (3), 409-426. doi: http://doi.org/ $10.1177 / 1468796809337432$

[32] Habib, I., Khan, I. A., Singh, K. P. (1976). Problems of the Muslim Minority in India. Social Scientist, 4 (11), 67-72. doi: http:// doi.org/10.2307/3516200

[33] Pandya, A. (2010). Muslim Indians Struggle for Inclusion. Washington: The Henry L. Stimson Center, 85.

[34] Statistical Data (2009). Interactive Data Table: World Muslim Population by Country. Available at: http://www.pewforum. org/2009/10/07/mapping-the-global-muslim-population23/

[35] Saloom, R. (2006). You Dropped a Bomb on Me, Denmark-a Legal Examination of the Cartoon Controversy and Response as it Relates to the Prophet Muhammad and Islamic Law. Rutgers Journal of Law and Religion, 8 (1), 3-17.

[36] Laborde, C. (2011). The Danish Cartoon Controversy and the Challenges of Multicultural Politics. Perspectives on Politics, 9 (3), 603-605. doi: http://doi.org/10.1017/s1537592711002817

[37] Statistical Data (2012). The National Archives. Part of 2011 Census, Key Statistics for Local Authorities in England and Wales Release. Available at: http://www.ons.gov.uk/ons/rel/census/2011-census/key-statistics-for-local-authorities-in-england-andwales/rpt-religion.html

[38] Border, J. (2006). Poll shows Muslims in Britain are the most anti-western in Europe. The Guardian. Available at: http://www. theguardian.com/world/2006/jun/23/uk.religion

[39] Faimau, G. (2013). British Christian Print Media and the Framing of Islam and Muslims through the Lens of Christian Persecution. Journal of Intercultural Studies, 34 (4), 340-355. doi: http://doi.org/10.1080/07256868.2013.807227

[40] U.S. Department of State. Lebanon 2012 International Religious Freedom Report. Available at: https://2009-2017.state.gov/j/ drl/rls/irf/2012//index.htm

[41] Dajani, N. (2012). Ethics and the Media: The Lebanese Experience. Conference on Bioethics in the Media. Available at: http:// www.aub.edu.lb/fm/shbpp/ethics/Documents/Ethics-and-the-Media-The-Lebanese-Experience.pdf

[42] Smith, C. S., Fisher, I. (2006, February 3). Temperatures Rise over Cartoons Mocking Muhammad. The New York Times. Available at: https://www.nytimes.com/2006/02/03/international/europe/03cartoons.html

[43] Bilefsky, D. (2006, January 8). Denmark is Unlikely Front in Islam-West Culture War. The New York Times. Source: https:// www.nytimes.com/2006/01/08/world/europe/denmark-is-unlikely-front-in-islamwest-culture-war.html? mtrref=undefined\&assetType $=$ REGIWALL

[44] Qureshi, E. (2006). The Islam the Riots Drowned Out. The New York Times. Available at: http://www.nytimes.com/2006/02/12/ opinion/12qureshi.html?_r=0

[45] Shaikh, T. (2006). Ten Killed as Cartoon Protests Spread to Libya. The Independent. Available at: http://www.independent.co.uk/news/world/middle-east/ten-killed-as-cartoon-protests-spread-to-libya-346232.html?origin=internal Search

[46] Greer, G. (2006). We've fallen for the street theatre of outrage. The Independent. Available at: https://www.independent.co.uk/ voices/commentators/germaine-greer-weve-fallen-for-the-street-theatre-of-outrage-5335310.html

[47] Masood, S. (2006). Two Killed in Violent Protests in Two Pakistani Cities. The New York Times. Available at: http://www. nytimes.com/2006/02/14/international/asia/14cnd-cartoon.html?fta $=\mathrm{y} \&$ _r $=0$

[48] Masood, S. (2006). 2 Die as Pakistan Cartoon Rage Turns Violent. The New York Times. Available at: http://www.nytimes. com/2006/02/15/international/middleeast/15cartoons.html

[49] Masood, S., O’neil, J. (2006). 3 More Die in Pakistan Cartoon Protests. The New York Times. Available at: http://www.nytimes.com/2006/02/15/international/asia/15cnd-pakistan.html 
[50] News Agency (2006). Five Held Over Cartoons Protest. The Independent. Available at: https://www.independent.co.uk/news/ uk/crime/five-held-over-cartoons-protest-469998.html

[51] Alibhai-Brown, Y. (2006). The Double Standards Over Free Speech. The Independent. Available at: https://www.independent. co.uk/voices/commentators/yasmin-alibhai-brown/yasmin-alibhai-brown-the-double-standards-over-free-speech-5335324.html

[52] Lane, I. G. (2009). The Extraordinary Renditions of Maher Arar and Abdullah Almalki: Orientalism, Islamophobia, and the Erosion of Citizenship and Human Rights. University of Prince Edward Island, 579. Available at: http://digitalcommons.ryerson.ca/cgi/viewcontent.cgi?article $=1581 \&$ context=dissertations

[53] Aretov, N. (2005). What is Occidentalism and Does it Have Ground at our House? International Interdisciplinary Conference Occidentalism. Available at: http://www.bulgc18.com/occidentalism/naretov_en.htm

[54] Zainagairi, H. (2006). Need for Introspection-I. Greater Kashmir. Available at: https://www.greaterkashmir.com/news/opinion/need-for-introspection-i/

[55] Zainagairi, H. (2006). A sentiment Deeply Hurt - I. Greater Kashmir. Available at: http://www.greaterkashmir.com/news/2006/ Feb/22/a-sentiment-deeply-hurt-i-10.asp

[56] Walia, H. (2006). The Row Over the Danish Cartoons. Dissident Voice. Available at: http://dissidentvoice.org/Feb06/Walia09.htm

[57] Freeman, S. (2006). First Deaths in Muhammad Cartoon Protests. The Times. Available at: http://www.thetimes.co.uk/tto/ news/world/article1983565.ece

[58] Pakistan's Premier NEWS Agency (2010). Kashmiri Organisation Felicitate Safi on his Election. Associated Press of Pakistan. Available at: https://web.archive.org/web/20150402183437/http://www.app.com.pk/en_/index.php?option=com_content\&task $=$ view\&id=93925\&Itemid=2

[59] GK News Service (2006). Publication of Prophet (SAW)'s Caricature Zionists' Conspiracy. Greater Kashmir. Available at: https://docs.google.com/document/d/1CPYXdT6OpEt4GWIkjCkywWAR1B5Jay_o0RYOMumu1m4/edit?usp=sharing

[60] Ouali, A. (2006). Arab Leaders Court Public Opinion in Cartoon Row: Experts. The Daily Star. Available at: http://www. dailystar.com.lb/News/Middle-East/2006/Feb-03/75008-arab-leaders-court-public-opinion-in-cartoon-row-experts.ashx\#axzz2vGjCmki4

[61] News (2006). India Muslims Urge Government to End Silence on Blasphemy. Greater Kashmir. Available at: https://docs. google.com/document/d/1CPYXdT6OpEt4GWIkjCkywWAR1B5Jay_o0RYOMumulm4/edit?usp=sharing

[62] Cowell, A. (2006). More European Papers Print Cartoons of Muhammad, Fueling Dispute with Muslims. The New York Times. Available at: http://query.nytimes.com/gst/fullpage.html?res=9C04E7D81F3FF931A35751C0A9609C8B63

[63] News Agency (2006). Danish Cartoonist: 'No Regrets'. The Independent. Available at: https://www.independent.co.uk/news/ world/europe/danish-cartoonist-no-regrets-6108797.html

[64] Lichfield, J. (2006). Anger as Paris Newspaper Prints Cartoon of Prophet. The Independent. Available at: https://www.independent.co.uk/news/world/europe/anger-as-paris-newspaper-prints-cartoon-of-prophet-6110058.html

[65] Sajid, A. (2005). Islamophobia: a New Word for an Old Fear. Anti-Semitism \& Islamophobia, 12 (2), 31-40.

[66] Brinkley, J., Fisher, I. (2006). U.S. Says it Also Finds Cartoons of Muhammad Offensive. The New York Times. Available at: http:/query.nytimes.com/gst/fullpage.html?res=9401E5D9163EF937A35751C0A9609C8B63

[67] Goodstein, L. (2006). U.S. Muslims Try to Ease Europe's Discord. The New York Times. Available at: https://www.nytimes. com/2006/02/13/world/americas/us-muslims-try-to-ease-europes-discord.html?mtrref=undefined\&gwh=42079BA048E1AEAF72F1C42421864B72\&gwt=pay\&assetType=REGIWALL\#0\&version=\&url=http:/query.nytimes.com/search/ sitesearch/?action=click\&region=Masthead\&pgtype=Homepage \&module=SearchSubmit\&contentCollection=Homepage $\& \mathrm{t}=$ qry172

[68] Anderson, B. (1991). Imagined Communities: Reflections on the Origin and Spread of Nationalism. London: Verso, 256.

[69] News (2006). Bar Condemns Desecration of Quran. Greater Kashmir. Available at: https://docs.google.com/document/d/1CPYXdT6OpEt4GWIkjCkywWARIB5Jay_o0RYOMumu1m4/edit?usp=sharing

[70] News Agencies (2006). Muslim Anger Boils Over Danish Cartoons. The Daily Star. Available at: http://www.dailystar.com.lb/ News/Middle-East/2006/Jan-31/74980-muslim-anger-boils-over-danish-cartoons.ashx\#axzz2vGjCmki4

[71] Pearl, J., Ahmed, A. (2006). For Jews and Muslims, Time to Find Common Ground. Daily Star. Available at: http://www. dailystar.com.lb/Opinion/Commentary/2006/Jan-23/96694-for-jews-and-muslims-time-to-find-common-ground.ashx\#ixzz30s2DBoRW

[72] Zainagiree, H. (2015). The Last Throw to the Dice. Greater Kashmir. Available at: https://www.greaterkashmir.com/news/ opinion/the-last-throw-to-the-dice/ 